\title{
Microtremors Measurement Around Dengkeng Fault Line in Central Java
}

\author{
Denny Darmawan ${ }^{1, *}$, M. Ilham N. Hafsyah ${ }^{1}$, Nugroho B. Wibowo ${ }^{2}$, Laila Katriani ${ }^{1}$, \\ Khafid N. Aziz ${ }^{1}$, Siti Patimah ${ }^{\mathbf{1}}$, Rofiki ${ }^{1}$, and Bambang Ruwanto ${ }^{1}$ \\ ${ }^{1}$ Physics Education Department, Universitas Negeri Yogyakarta, Indonesia \\ ${ }^{2}$ Meteorological, Climatological \& Geophysical Agency of Indonesia \\ *Corresponding author.Email: darmawan@uny.ac.id
}

\begin{abstract}
Microtremor signals measurement had been conducted in area surrounding Dengkeng Fault line in Central Java, Indonesia. This research is aimed to identify the characteristics of area surrounding Dengkeng fault line and to identify the Dengkeng fault line through microtremors parameters analysis. Microtremor signals were obtained from field measurement using TDV-23/TDL-303 Taide Digital Portable Seismograph and were analyzed using Horizontal to Vertical Spectral Ratio (HVSR) method. There were 48 stations with $2 \mathrm{~km}$ spacing between stations that covers the area around Dengkeng fault line. The results showed that the microzonation of microtremor parameters in the area around Dengkeng Fault line are in good agreement with the geological setting of the research area depicted in official geological map. They also showed that Dengkeng Fault line is located in geological formation boundary between Gunungapi Merapi Muda formation and Kebobutak formation as previously predicted and mostly striking East-West.
\end{abstract}

Keywords: Dengkeng Fault, Microtremors, HVSR method.

\section{INTRODUCTION}

Dengkeng fault line is a local fault located at Klaten Regency in Central Java. The rumoured existence of this fault emerged after the Yogyakarta earthquake on 27 May 2006 which took more than 5000 fatalities [1], along with the existence of Opak Fault which was presumed to be the source for the earthquake [2]. Its orientation is predicted to be in East-West direction and connected to Opak Fault line which is striking NorthSouth $[3,4]$. However, its existence is not depicted in the official geological map [5].

Based on the Yogyakarta earthquake fatalities distribution [1], there is a strong presumption that Dengkeng Fault do exist, the same with Opak Fault. The existence of this fault raises concerns when Meteorological, Climatological \& Geophysical Agency of Indonesia recorded that during 2015 - 2019 there were at least 10 small and shallow earthquakes epicentered around the fault. However, there are only a few academic studies on this fault. This is quite different with Opak Fault which gained more attention $[3,6-9]$ and its presumed line is depicted in an official geological map [10]. This research is expected to add the academic study on Dengkeng Fault and is also aimed to identify the fault line through microtremor parameters analysis thus supporting the evidences for the existence of the fault.

\section{METHOD}

The research area was confined within geographical coordinates of $7^{\circ} 44^{\prime} 10.94^{\prime \prime} \mathrm{S}$ to $7^{\circ} 49^{\prime} 52.20^{\prime \prime} \mathrm{S}$ and $110^{\circ} 30^{\prime} 16.53^{\prime \prime} \mathrm{E}$ to $110^{\circ} 37^{\prime} 9.54^{\prime \prime} \mathrm{E}$, covering 5 subdistrict which are Bayat and Prambanan in Klaten Regency, Patuk and Gedangsari in Gunungkidul Regency and Piyungan in Bantul Regency. There were 48 measurement sites (stations) in the area distributed in a grid form with $2 \mathrm{~km}$ spacing between stations. Some stations were displaced to accommodate the requirement from SESAME Project guidelines [11].

Microtremor signals were measured for about 30 minutes at each stations using TDV-23S/TDL-303S Taide Digital Portable Seismograph with sampling frequency of $100 \mathrm{~Hz}$. The signals were then processed by HVSR method [12] using OpenHVSR software $[13,14]$ to get $H / V$ curves. From these curves, microzonation of predominant frequency and 
amplification factor, directional amplification in the form of rose diagrams, and $\mathrm{H} / \mathrm{V}$ cross sections around the Dengkeng Fault line were obtained and interpreted.

\section{RESULTS AND DISCUSSION}

\subsection{Seismicity of The Research Area}

During 2015 - 2019, ten small and shallow earthquakes epicentered around the Dengkeng Fault line was recorded by Meteorological, Climatological \& Geophysical Agency's stations. The distribution of the earthquakes' epicenter is shown in Figure 1. The dashed lines in the northern area of Figure 1 is the presumed Dengkeng Fault line according to Supartoyo [4]. The earthquakes have $1.7-2.5$ magnitude and $4-15 \mathrm{~km}$ depth. These small and shallow earthquakes indicate local fault activities around the area that occupied by several small fault lines. However, since the Dengkeng Fault line is located in the boundary of two geological formation, which are Gunungapi Merapi Muda and Kebobutak, and most of the earthquakes took place in both geological formation, it can be considered that the activities come from the fault line.

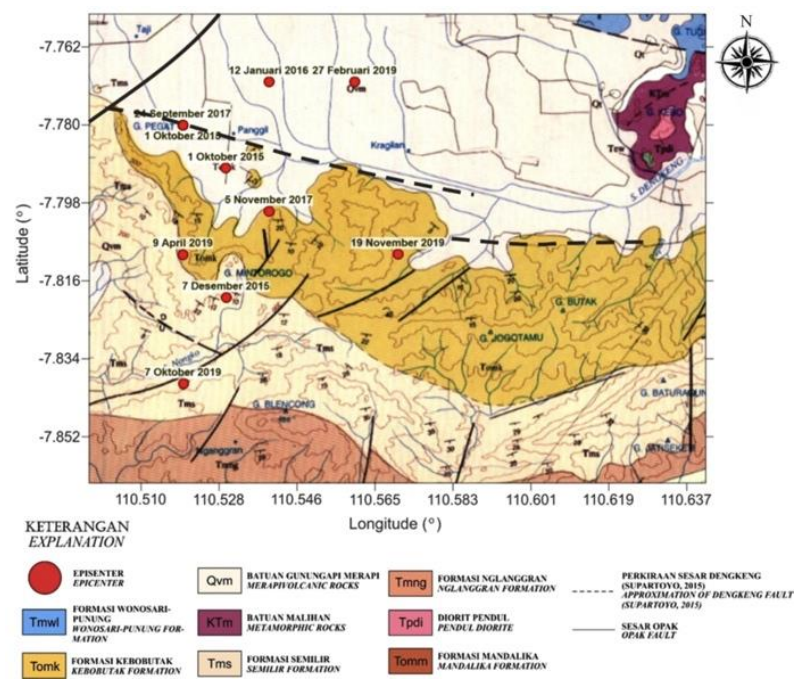

Figure 1 Seismicity map for 2015 - 2019 period around Dengkeng Fault line overlayed with geological map.

\subsection{Microzonation of Predominant Frequency}

The distribution of predominant frequency around Dengkeng Fault line is shown in Figure 2. The predominant frequency ranges between $0.2 \mathrm{~Hz}$ and 14.39 Hz. It can be seen that the lower values dominate the northern side of the fault which is related to Gunungapi Merapi Muda formation. These lower values indicate that the northern side of the fault line is mostly covered by thicker sediment compared to the southern side of the fault line. This thick sediment comprises mostly of sand, tuff and ash [10] which could be produced by Mount Merapi's activities located in the North direction of the research area but also can be produced from the weathering process taken place in the hilly area of the southern side of the fault line. The difference in the sediment thickness is in accordance with the difference in geological formation, which is Gunungapi Merapi Muda formation in the northern side of the fault line and Kebobutak formation in the southern side of the fault line [5]. Kebobutak formation mostly comprises of andesitic-breccia and lapilli tuff which can be considered to be hard rocks [10]. It explains the lower predominant frequency in this area.

However, based on Figure 2, not all areas in the southern side of Dengkeng Fault line have higher predominant frequency although they have the same geological formation. Weathering process could be the cause for this discrepancy. Southwestern part of the research area is also located in different geological formation which is Semilir formation. This formation comprises of pumice breccia and tuffaceous claystone [10] which can be considered to be softer than Kebobutak formation and explain the lower predominant frequency in the area.

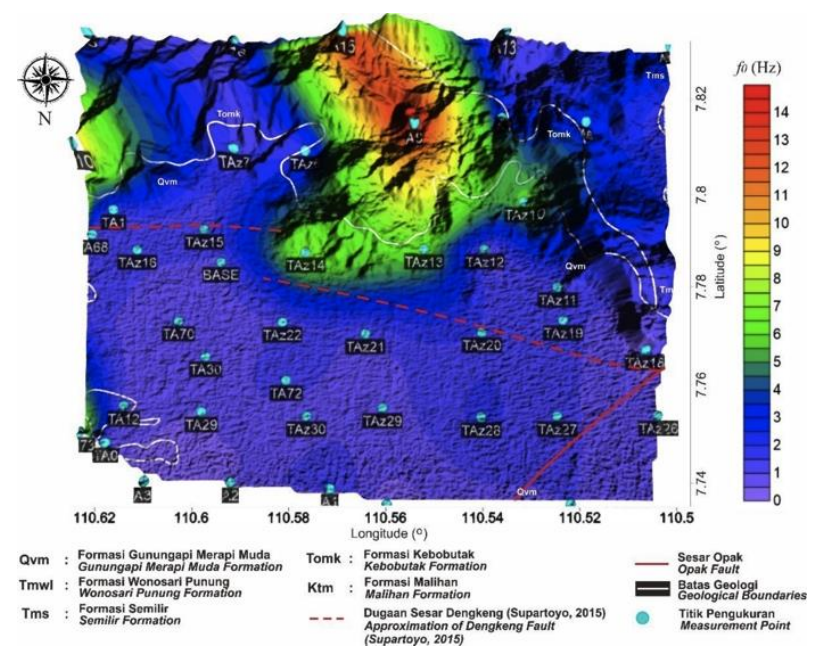

Figure 2 Microzonation of predominant frequency around Dengkeng Fault line.

\subsection{Microzonation of Amplification Factor}

The distribution of amplification factor around Dengkeng Fault line is shown in Figure 3. The amplification factor ranges between 2.19 and 11.82. It can be seen that the distribution of amplification factor in the research area is in good agreement with the distribution of predominant frequency. Kebobutak formation in the southern side of the fault line with higher predominant frequency has lower amplification factor which describes denser rocks in the area compared to the other. Semilir formation in the southwestern side of the fault line also has lower amplification factor since it is still considered to be hard rocks eventhough it is softer than Kebobutak formation. The Kebobutak formation in the southeastern side of the 
fault line which has lower predominant frequency also seems to have relatively higher amplification factor which describes the less dense rocks compared to the southern side of the fault line which has the same formation. Again, weathering process could be the cause for this discrepancy.

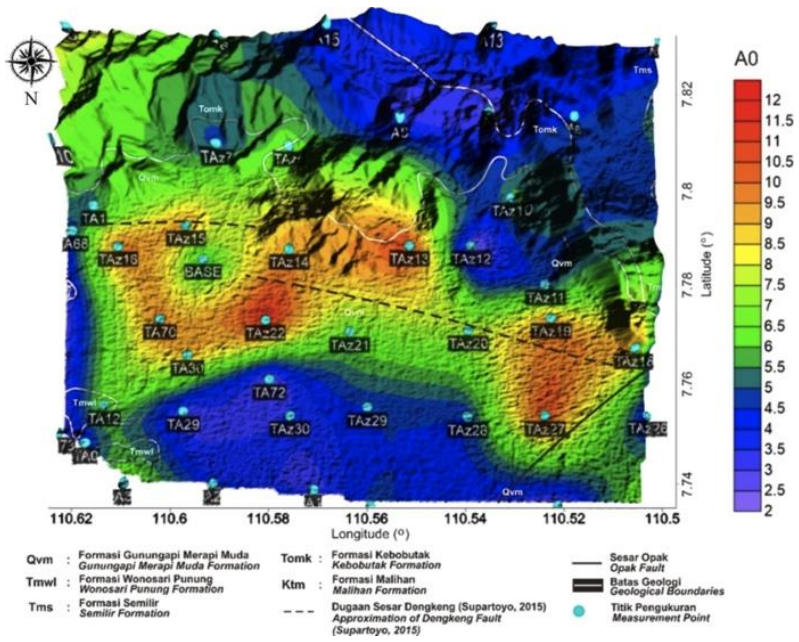

Figure 3 Microzonation of amplification factor around Dengkeng Fault line.

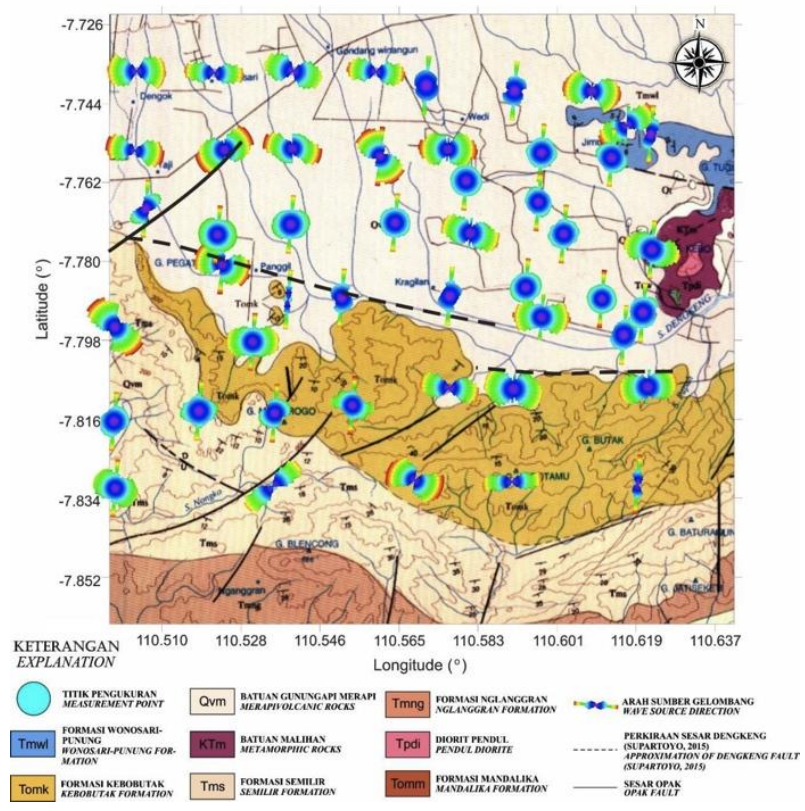

Figure 4 Distribution of directional amplification around Dengkeng Fault line overlayed with geological map.

The most interesting feature in the amplification factor distribution is the distribution along the fault line. As can be seen from Figure 3, the amplification factor is higher along the fault line which describe the less dense rocks, and relatively lower in the far northern side of the fault line which describes denser rocks. This difference in amplification factor eventhough they are in the same geological formation which is Gunungapi Merapi Muda formation indicates that geological deformation has occurred along the fault line. It supports the evidences of the existence of Dengkeng Fault line in the research area which was previously only rumoured.

From microtremor data, we can also generate the rose diagrams of amplification factor and its azimuth that describe the directional amplification as can be seen from Figure 4. Directional amplification is mostly perpendicular to the strike of measured faults [15]. Based on Figure 4, around $60.4 \%$ or 29 of 48 diagrams has North-South orientation which indicates that there is a fault line oriented to the East-West direction which is in accordance with the Dengkeng Fault depicted by Supartoyo [4]. The percentage cannot exceed $90 \%$ since there are several fault lines around the research area. However, 60.4\% indicates that the Dengkeng Fault line could be the major fault lines in the area.

\subsection{H/V Cross Sections}

Using the H/V curves obtained from HVSR method, $\mathrm{H} / \mathrm{V}$ cross sections which depict the sediment thickness around the fault line can be generated (Figure 6). Any abrupt changes in the sediment thickness can be related to the existence of a fault line [16]. Seven cross section lines were used to see the sediment thickness profiles in the fault line area (Figure 5). The lines were drawn perpendicular to the fault line predicted by Supartoyo [4]. H/V cross sections of the second to seventh line are presented in Figure 6 which include the topographical profile along the line for each cross section. As can be seen in the topographical profile for each cross section, the southern side of the research area has higher elevation since it is mostly a hilly area.

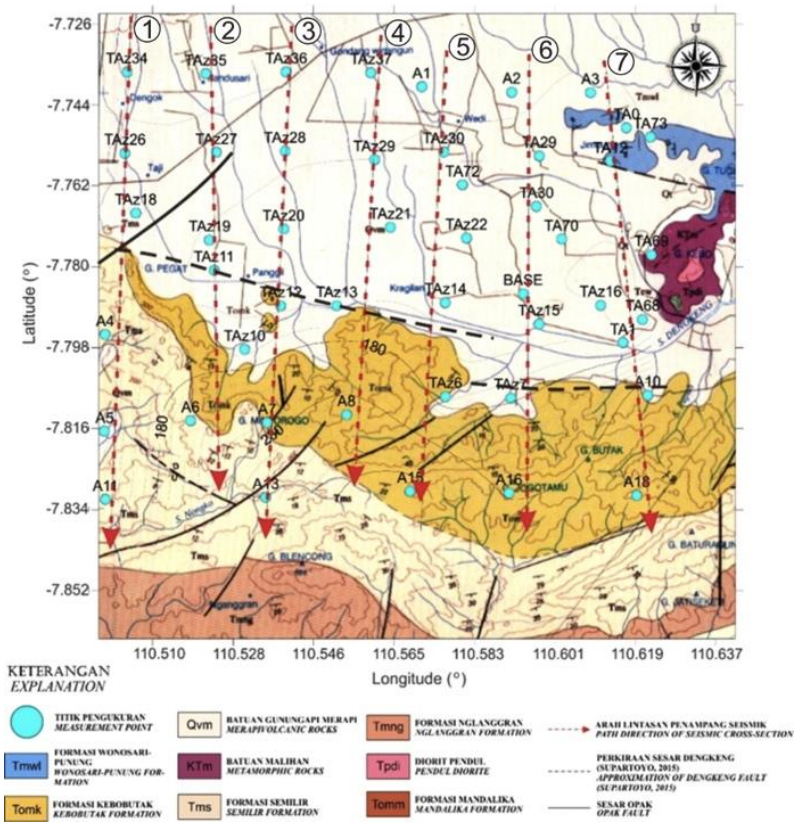

Figure 5 Distribution of cross section lines around Dengkeng Fault line overlayed with geological map. 
As can be seen from depth profile in Figure 6, there are abrupt changes in sediment thickness around the fault line. This feature support the argument that Dengkeng Fault line is located in the geological formation boundary as depicted by Supartoyo [4], since Gunungapi Merapi Muda formation has thicker sediment thickness compared to Kebobutak formation.

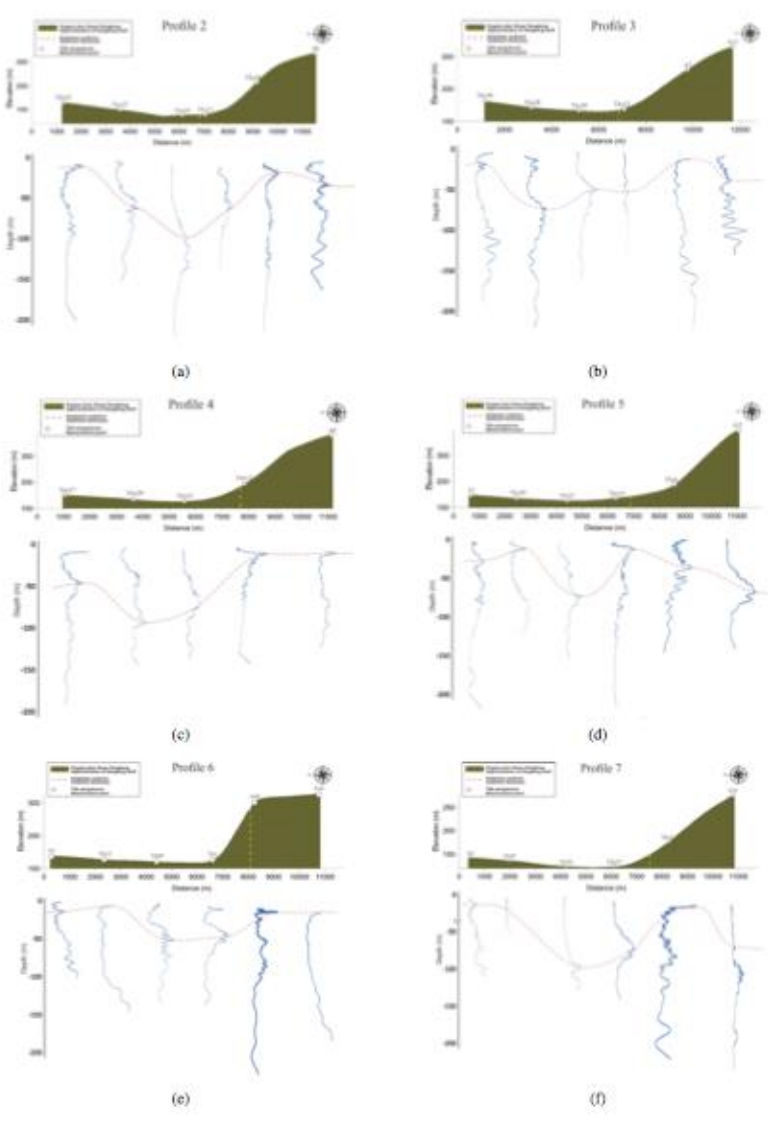

Figure 6 H/V Cross Section for (a) Profile 2, (b) Profile 3, (c) Profile 4, (d) Profile 5, (e) Profile 6 and (f) Profile 7

\section{CONCLUSIONS}

The microtremors parameters analysis results show good agreement with the geological setting of the research area depicted by official geological map. Microzonation of predominant frequency is in good agreement with the geological formation setting where the northern side of the Dengkeng Fault line is mostly consisted of thick sediment related to Gunungapi Merapi Muda formation and the southern side of the fault line is mostly consisted of thin sediment related to Kebobutak formation. Microzonation of amplification factor in the area shows less dense rocks along the Dengkeng Fault line, probably were generated by faulting. The directional amplification distribution shows that the fault line is mostly striking East-West and $\mathrm{H} / \mathrm{V}$ cross section analysis results shows that the fault line is located along the geological formation boundary between Gunungapi Merapi Muda formation and Kebobutak formation. However, this conclusion need to be compared with other geophysical methods.

\section{AUTHORS' CONTRIBUTIONS}

DD and MINH contributed to the writing of the manuscript. DD, MINH, NBW, KNA, R and SP contributed to the survey design, field measurements and data analysis. DD, MINH and NBW contributed to the interpretation of the results. LK and BR contributed to giving critical feedback to the manuscript.

\section{ACKNOWLEDGMENTS}

This research was funded by Universitas Negeri Yogyakarta (UNY) through DIPA UNY (Contract No. B/193/UN34.13/PM.01.01/2020). The authors would like to thanks UNY for the research fund, and also the anonymous reviewers for their suggestions.

\section{REFERENCES}

[1] Consultative Group on Indonesia, Penilaian Awal Kerusakan dan Kerugian Bencana Alam di Yogyakarta dan Jawa Tengah, Laporan bersama Bappenas, Pemprov D.I.Yogyakarta, Pemprov Jawa Tengah dan Mitra Internasional, 2006.

[2] Supartoyo, O. Abdurahman, A. Kurnia, 10 Tahun Gempa Yogyakarta, Geomagz, vol. 6, no.2, 2016 p.18-23

[3] H.Z. Abidin, H. Andreas, I. Meilano, M. Gamal, I. Gumilar, C.I. Abdullah, Deformasi Koseismik dan Pascaseismik Gempa Yogyakarta 2006 dari Hasil Survei GPS, Jurnal Geologi Indonesia, vol. 4, 2009, p.275-284

[4] Supartoyo, Mengenal Sesar Aktif, Geomagz, vol.5 no. 2, 2015, p.92-97

[5] Surono, B. Toha, I. Sudarno, Peta Geologi Lembar Surakarta-Giritontro, Jawa (Geological Map of The Surakarta-Giritontro Quadrangles, Jawa), Pusat Penelitian dan Pengembangan Geologi, 1992.

[6] M.I. Nurwidyanto, R.D. Indriana, Z.T. Darwis, Pemodelan Zona Sesar Opak di Daerah Pleret Bantul Yogyakarta Dengan Metode Gravitasi, Berkala Fisika, vol.10, 2007, p.65-70

[7] T.R. Walter, R. Wang, B.G. Luehr, J. Wassermann, Y. Behr, S. Parolai, A. Anggraini, E. Gunther, M Sobiesiak, H. Grosser, H.U. Wetzel, C. Milkereit, P.J.K. Sri Brotopuspito, P. Harjadi, J. Zschau, The 26 May 2006 Magnitude 6.4 Yogyakarta Earthquake South of Mt. Merapi Volcano: Did Lahar Deposits Amplify Ground Shaking and Thus 
Lead to The Disaster?, Geochemistry Geophysics Geosystem, vol. 9, 2008, p.1-9

[8] M. Marsyelina, N.B. Wibowo, D Darmawan, Karakteristik Mikrotremor dan Analisis Seismisitas Pada Jalur Sesar Opak, Kabupaten Bantul, Yogyakarta, Jurnal Sains Dasar, vol. 3, 2014, p.95-101

[9] D.N. Dayana, N.B. Wibowo, D. Darmawan, Interpretasi Struktur Bawah Permukaan Jalur Sesar Opak Berdasarkan Model Suseptibilitas dan Second Vertical Derivative dengan Metode Geomagnet, Indonesian Journal of Applied Physics, vol.8, 2018, p.88-98

[10] W. Rahardjo, Sukandarrumidi, H.M.D. Rosidi, Peta Geologi Lembar Yogyakarta, Jawa (Geological Map of The Yogyakarta Sheet, Jawa), Pusat Penelitian dan Pengembangan Geologi, 1995.

[11] SESAME European Research Project, Guidelines For The Implementation Of The H/V Spectral Ratio Technique On Ambient Vibrations: Measurements, Processing And Interpretation, European Commission-Research General Directorate, 2004.

[12] Y. Nakamura, A Method For Dynamic Characteristic Estimation of Subsurface Using Microtremor On The Ground Surface, Quarterly Report of RTRI, vol.30, 1989, p.1

[13] S. Bignardi, N. Abu Zeid, A. Mantovani, OpenHVSR: Imaging The Subsurface 2D/3D Elastic Properties Through Multiple HVSR Modeling and Inversion, Computers \& Geosciences, vol.93, 2016, p.103

[14] S. Bignardi, A.J. Yezzi, S. Fiussello, Comelli, OpenHVSR Processing Toolkit: Enhanced HVSR Processing of Distributed Microtremor Measurements and Spatial Variation of Their Informative Content, Computers \& Geosciences, vol.120, 2018, p.10-20

[15] M. Pischiutta, M. Fondriest, M. Demurtas, F. Magnoni, G. Di Toro, A. Rovelli, Structural Control On The Directional Amplification of Seismic Noise (Campo Imperatore, Central Italy), Earth and Planetary Science Letters, vol.471, 2017, p.10

[16] M. Khalili, A.V. Mirzakurdeh, Fault Detection Using Microtremor Data (HVSR-Based Approach) and Electrical Resistivity Survey, Journal of Rock Mechanics and Geotechnical Engineering, vol.11, 2019, p.400 